\title{
FAKTOR PENENTU KEBIJAKAN HUTANG PERUSAHAAN MANUFAKTUR DI BURSA EFEK INDONESIA PERIODE 2016 - 2018
}

\author{
Jumaidi A W ${ }^{1}$, Nuri Angelina Saragih ${ }^{2}$, Azizul Kholis ${ }^{3}$ \\ Universitas Negeri Medan ${ }^{1}$, Universitas Negeri Medan ${ }^{2}$, Universitas Negeri Medan ${ }^{3}$ \\ jumiadi@unimed.ac.id ${ }^{1}$, nuri.anagelina.saragih@wbi.ac.id ${ }^{2}$, azizulkholis@ unimed.ac.id ${ }^{3}$
}

\begin{abstract}
ABSTRAK
Penelitian ini bertujuan untuk mengetahui pengaruh kepemilikan institusional terhadap kebijakan hutang, pengaruh ukuran perusahaan terhadap kebijakan hutang, pengaruh profitabilitas terhadap kebijakan hutang, pengaruh pertumbuhan penjualan terhadap kebijakan hutang, dan pengaruh kepemilikan institusional, ukuran perusahaan, profitabilitas dan pertumbuhan penjualan secara bersamaan terhadap kebijakan hutang pada perusahaan manufaktur yang terdaftar di Bursa Efek Indonesia periode 2016 - 2018. Populasi dalam penelitian ini adalah seluruh perusahaan manufaktur yang terdaftar di BEI periode 2016 - 2018. Pemilihan sampel menggunakan metode purposive sampling. Berdasarkan kriteria yang telah ditentukan, diperoleh sampel sebanyak 34 perusahaan, dengan tiga tahun pengamatan sehingga data observasi berjumlah 102 pengamatan. Teknik analisis data yang digunakan adalah analisis statistik deskriptif, uji asumsi klasik, analisis regresi linear berganda, uji hipotesis, dan koefisien determinasi (R2). Hasil dari penelitian ini menunjukkan bahwa kepemilikan institusional berpengaruh negatif signifikan terhadap kebijakan hutang dengan nilai T-hitung -2.803 > nilai T-tabel sebesar -1,98472 dengan tingkat signifikansi 0,006 $<0,05$, ukuran perusahaan tidak berpengaruh terhadap kebijakan hutang dengan nilai T-hitung sebesar -0,621 < nilai T-tabel sebesar 1,98742 dengan tingkat signifikansi 0,536 >0,05, profitabilitas berpengaruh negatif signifikan terhadap kebijakan hutang dengan nilai T-hitung sebesar -6,709 > nilai T-tabel sebesar 1,98742 dengan tingkat signifikansi 0,000 $<0,05$, pertumbuhan penjualan berpengaruh positif dan signifikan terhadap kebijakan hutang dengan nilai T-hitung sebesar 2,922 > nilai T-tabel sebesar 1,98742 dengan tingkat signifikansi $0,004<0,05$, dan kepemilikan institusional, ukuran perusahaan, profitabilitas, dan pertumbuhan penjualan secara bersamaan berpengaruh positif dan signifikan terhadap kebijakan hutang dengan nilai F-hitung 14,241 > F-tabel 2,47 dengan tingkat signifikansi sebesar 0,000 <0,05. Kesimpulan penelitian ini adalah kepemilikan institusional, profitabilitas dan pertumbuhan penjualan secara parsial maupun simultan berpengaruh terhadap kebijakan hutang, namun ukuran perusahaan tidak berpengaruh secara parsial terhadap kebijakan hutang. Hal ini berarti beberapa faktor - faktor tersebut mampu mempengaruhi kebijakan hutang pada perusahaan manufaktur yang terdaftar di Bursa Efek Indonesia.
\end{abstract}

Kata Kunci: kebijakan, hutang,profitabilitas, 


\section{PENDAHULUAN}

Pendanaan merupakan salah satu komponen yang dianggap wajar dan penting dalam keberlangsungan hidup suatu perusahaan di era gelobalisasi saat ini. Untuk menjalankan operasinya setiap perusahaan memiliki berbagai kebutuhan, terutama yang berkaitan dengan dana agar perusahaan dapat berjalan sebagaimana mestinya. Tujuan perusahaan yaitu mencakup pertumbuhan yang terus menerus, keberlangsungan hidup, dan kesan yang positif dimata publik. Untuk dapat mencapai tujuan tersebut tentu sangat diperlukan dana dan modal yang sangat besar dalam mendukung segala aktivitas yang ada baik didalam perusahaan maupun diluar perusahaan. Dana selalu dibutuhkan untuk menutupi seluruh atau sebagian dari biaya yang diperlukan, baik dana jangka pendek maupun jangka panjang. Secara umum sumber modal ada dua alternative yaitu modal yang bersumber dari modal sendiri atau dari ekternal seperti pinjaman/utang. Pendanaan dengan modal sendiri dapat dilakukan dengan menerbitkan saham (stock), sedangkan pendanaan dengan utang (debt) dapat dilakukan dengan menerbitkan obligasi (bonds), right issue atau berutang ke bank, mitra bisnis.

Sumber dana ekternal digunakan ketika dana internal perusahaan tidak mencukupi untuk biaya operasional perusahaan, dana ekternal tersebut sering disebut Hutang. Sebagian perusahaan menganggap bahwa penggunaan hutang dirasa lebih aman daripada menerbitkan saham baru. Babu dan Jain (1998) dalam Nafisa (2016) menyatakan bahwa terdapat empat alasan mengapa perusahaan lebih suka menggunakan hutang daripada saham baru yaitu :

(1) Adanya manfaat pajak atas pembayaran bunga

(2) Biaya transaksi pengeluaran hutang lebih murah daripada biaya transaksi emisi saham baru (3) Lebih mudah mendapatkan pendanaan hutang daripada pendanaan saham (4) Kontrol manajemen lebih besar adanya hutang baru daripada saham baru.

Beberapa perusahaan Unicorn di Indonesia yang tetap axis melalui pendanaan berupa hutang dari pihak eksternal salah satunya adalah Go-Jek. Gojek membuka pendanaan baru yang bersumber dari Google, Tencent, dan JD.com dengan jumlah Rp.12,9 Triliun atau US\$920 juta. Yang kedua yaitu Tokopedia, Tokopedia memperoleh pendanaan yang bersumber dari Softbank dan Alibaba Group senilai US\$1,1 Milliar atau sekitar Rp.15,9 Triliun. Yang ketiga yaitu Traveloka, Traveloka memperoleh pendanaan dari Expedia,GFC, dan Sequoia Capital dari AS, Hillhouse Capital dan JD.com dari China senilai US\$ 500 juta (detikfinance, 20 Maret 2019). Pemilihan keputusan pendanaan dalam bentuk hutang yang dilakukan oleh pihak manajer akan ternilai baik apabila dana ekternal tersebut digunakan tepat sasaran karena hutang berfungsi untuk memonitoring tindakan para manajer dalam mengelola perusahaan.

Sebagai contoh kasus lain, Uber mengalami kerugian lebih dari US\$ 1 Miliar atau lebih dari Rp 14 Triliun di kuartal I tahun 2019. Hal ini Karena keputusannya untuk menyerahkan operasinya di dua Negara kepada pesaingnya dan melalukan pendanaan lain yaitu dengan menjual sahamnya kepada publik namun harga saham tidak sesuai dengan harapan (detikfinance, 31 Mei 2019). Kerugian yang dialami Uber menjadi pesan penting bagi pihak perusahaan untuk mengelola sumber dana secara lebih baik lagi serta mempertimbangkan kebijakan pendanaan yang tepat. Kebijakan hutang merupakan bagaimana tindakan suatu perusahaan dalam mengambil langkah, keputusan dalam memperoleh dana atau modal perusahaan yang diperoleh baik dari penerbit surat hutang (obligasi), saham maupun dari laba ditahan (Santi Herawati, 2010). Berdasarkan fenomena diatas sejalan dengan pecking order theory yaitu mengutamakan penggunaan dana internal setelah itu melakukan pendanaan berupa hutang yang bertujuan untuk meningkatkan pertumbuhan penjualan dan laba perusahaan.

Pada dasarnya terdapat banyak faktor yang mempengaruhi kebijakan hutang, diantaranya yaitu kepemilikan manajerial, kepemilikan institusional, struktur aset, kebijakan deviden, profitabilitas, ukuran perusahaan, free cash flow dan pertumbuhan perusahaan, Dwi dkk (2012), Ramadhany, dkk (2015), Ifada \& Yunandriatna (2017). 
Hal ini didasari karena banyaknya penelitian empiris terdahulu yang telah menguji faktor-faktor yang mempengaruhi kebijakan Hutang. Dalam penelitian ini Kepemilikan institusional (KI) diukur berdasarkan tingkat kepemilikan saham oleh pihak institusional dalam perusahaan sebagai salah satu variabel independen. Peneliti terdahulu yang juga meneliti pengaruh kepemilikan institusional terhadap kebijakan hutang yaitu Astuti (2014). Hasil dari penelitian ini menyimpulkan bahwa Kepemilikan Institusional tidak berpengaruh signifikan terhadap kebijakan hutang. Senada dengan penelitian yang dilakukan oleh Syadeli (2013), Narita (2012), Djabid (2009), Indana (2015), Dwi dkk (2012), Ahyuni (2018), ini berarti kepemilikan institusional tidak dapat menggantikan peranan hutang dalam memonitor manajemen perusahaan. Penelitian ini tidak sejalan dengan hasil penelitian Nuraina (2012), Indahningrum \& Ratih (2009), Larasati (2011), Murtiningtyas (2012), Tjeleni (2013), bahwa kepemilikan institusional berpengaruh signifikan dan positif terhadap kebijakan Hutang, dimana hal ini menggambarkan bahwa naiknya kepemilikan institusional akan menyebabkan kenaikan pula pada hutang perusahaan.

Ukuran perusahaan merupakan skala pengukuran atas suatu perusahaan baik dari segi aset, penjualan ataupun jumlah tenaga kerja dalam mengambil peluang bisnis yang ada. Ukuran perusahaan menjadi faktor yang perlu dipertimbangkan dalam menentukan kebersediaan pihak ketiga untuk memberikan pinjaman. Ukuran perusahaan dalam penelitian ini diukur dengan melihat total aktiva. Hasil dari penelitian terdahulu Astuti (2014) bahwa ukuran perusahaan berpengaruh positif terhadap kebijakan hutang. Hal ini sejalan dengan penelitian yang dilakukan oleh Irawan dkk (2016), Syadeli (2013), Dwi dkk (2012), Ifada \& Yunandriatna (2017), Yuana dkk (2018) dimana hal ini menunjukkan bahwa semakin besar ukuran perusahaan maka lebih mudah untuk memperoleh pinjaman dibandingkan perusahaan kecil, karena jaminan yang dimiliki berupa aktiva (aset) lebih besar dibandingkan perusahaan kecil. Namun tidak senada dengan penelitian yang dilakukan Nuraina (2012), Narita (2012), Darmayanti (2012), dimana ukuran perusahaan tidak memiliki pengaruh terhadap kebijakan hutang. Hal ini berarti besar atau kecilnya sebuah perusahaan tidak menjamin perusahaan memiliki kondisi pasar yang konsisten dimasa mendatang sehingga perusahaan tidak ingin menanggung resiko dengan mengambil keputusan menggunakan hutang sebagai sumber pendanaannya.

Profitabilitas merupakan kemampuan perusahaan dalam menghasilkan laba atau keuntungan. Perusahaan dengan tingkat pengembalian investasi yang tinggi dapat melakukan permodalan dengan laba ditahan yang merupakan pendanaan internal perusahaan seperti halnya pertumbuhan penjualan yang merupakan kenaikan jumlah penjualan dari tahun ke tahun. Semakin tinggi tingkat pertumbuhan penjualan perusahaan maka akan meningkatkan laba dan kemungkinan untuk menggunakan hutang akan rendah, karena laba dari penjualan tersebut dapat menutupi biaya operasional ditahun mendatang sehingga cenderung menurunkan tingkat hutang perusahaan (Amirya \& Atmini, 2008). Penelitian terdahulu Astuti (2014) yang meneliti pengaruh profitabilitas terhadap kebijakan hutang menyatakan bahwa profitabilitas berpengaruh postif dan signifikan. Senada dengan penelitian Narita (2012), dimana berarti bahwa pada kondisi perusahaan yang memiliki tingkat profitabilitas cukup tinggi dengan kesempatan investasi yang terbatas, manajemen lebih menyukai sumber pendanaan dari hutang. Hal ini tidak sejalan dengan penelitian yang dilakukan oleh Irawan dkk (2016), Syadeli (2013), Indahningrum \& Ratih (2009), Darmayanti (2012),

Murtiningtyas (2012), Dwi dkk (2012), Kusrini (2012), Ahyuni (2018) Yuana dkk (2018) dimana profitabilitas berpengaruh negatif signifikan terhadap kebijakan Hutang. Hal ini berarti perusahaan yang memiliki profitabilitas yang tinggi lebih memilih untuk memanfaatkan dana internal seperti laba ditahan dalam membiayai operasional perusahaan sehingga tidak membutuhkan dana yang bersumber dari Hutang.

Menurut Brigham dan Houston (2011:39), menyatakan perusahaan dengan penjualan yang relatif stabil dapat lebih memperoleh banyak pinjaman dibandingkan dengan perusahaan yang penjualan tidak stabil, karena kebutuhan dana yang digunakan suatu perusahaan dengan tingkat penjualan yang tinggi akan semakin besar. Pertumbuhan 
perusahaan dapat mempengaruhi kepercayaan kreditur terhadap perusahaan dan kesediaan pemodal untuk memberikan pendanaan melalui utang jangka panjang (Firnanti, 2011). Beberapa peneliti terdahulu seperti Pradhana, dkk (2014), Margaretha (2014), Susanti (2014), Yuana dkk (2018) menyatakan bahwa pertumbuhan penjualan tidak berpengaruh terhadap kebijakan hutang. Hal ini mengindikasikan bahwa tidak semua perusahaan yang mempunyai tingkat pertumbuhan penjualan yang tinggi memilih hutang sebagai sumber pendanaannya. Namun berbeda dengan hasil penelitian yang dilakukan oleh Mardiyati, dkk (2018), Syaifudin (2013), Mulyati (2016), Sudiyanto \& Septavia (2013), yang menyatakan bahwa pertumbuhan penjualan memiliki pengaruh terhadap kebijakan hutang. Hal ini mengindikasikan bahwa perusahaan yang memiliki tingkat pertumbuhan penjualan yang tinggi cenderung membutuhkan dana ekternal yang lebih besar. Selain itu para investor juga akan menilai dan yakin kepada perusahaan jika perusahaan tersebut dapat mengelola utangnya dengan baik dan mampu menangani risiko atas utang tersebut, sehingga perusahaan akan menambah tingkat hutangnya.

Berdasarkan Teori dan adanya fenomena yang telah dijelaskan melalui beberapa perusahaan yang mampu meningkatkan kinerja perusahaannya dan beberapa perusahaan yang tidak mampu meningkatkan kinerja bahkan tidak dapat mengelola hutangnya dengan baik hingga jatuh bangkrut, kemudian dilihat juga berdasarkan rata - rata DER yang berfluktuatif pada data beberapa perusahaan dan dikarenakan adanya ketidakkonsitenan dari hasil penelitian terdahulu maka penulis tertarik untuk melakukan penelitian kembali terkait Kebijakan Hutang untuk melihat bahwa pemilihan sumber dana ekternal tidaklah salah apabila sumber dana ekternal dikelola dengan baik, maka akan mendorong pertumbuhan kinerja perusahaan juga. Oleh karena itu dalam pemilihan kebijakan hutang diperlukan juga dukungan dari faktor - faktor seperti Kepemilikan Institusional, Ukuran Perusahaan, Profitabilitas, Pertumbuhan Penjualan. Penelitian ini merupakan pengembangan dari penelitian yang dilakukan oleh Astuti (2014). Hal yang membedakan penelitian ini dengan penelitian sebelumnya adalah penambahan variabel pertumbuhan penjualan, sampel dan tahun penelitian. Terpilih nya variabel pertumbuhan penjualan dikarenakan pertumbuhan penjualan merupakan salah satu faktor yang dipertimbangkan dalam keputusan utang. Perusahaan yang memiliki tingkat pertumbuhan yang tinggi cenderung menggunakan dana dari sumber eksternal yang besar.

Menurut Agus Sartono dalam (Fahmi 2017:206) bahwa tingkat pertumbuhan di masa mendatang apabila tingkat pertumbuhannya tinggi, maka leverage lebih besar begitu juga sebaliknya. Penelitian sebelumnya dilakukan pada perusahaan yang listing di BEI pada tahun 2012 dan hanya satu tahun. Sedangkan penelitian ini dilakukan pada perusahaan manufaktur yang terdaftar di BEI periode tahun 2016 - 2018. Perusahaan terdiri atas tiga jenis yaitu perusahaan jasa, dagang, dan manufaktur. Peneliti memilih perusahaan manufaktur sebagai objek penelitian dikarenakan perusahaan manufaktur memiliki skala produksi yang cukup besar dan aktivitas produksi yang berkesinambungan sehingga membutuhkan modal yang besar pula untuk mengembangkan produk dan ekspansi pasarnya. Perusahaan manufaktur terdiri dari berbagai sektor yaitu sektor industri dan kimia, sektor aneka industri dan sektor industri barang konsumsi. Dan dilihat dari jumlah perusahaannya, perusahaan manufaktur lebih banyak dibandingkan jumlah perusahaan lainnya sehingga dapat memenuhi kriteria dalam penentuan sampel penelitian.

Berdasarkan latar belakang diatas, makamasalah penelitian ini adalah : "Pengaruh Kepemilikan Institusional, Ukuran Perusahaan, Profitabilitas Dan Pertumbuhan Penjualan Terhadap Kebijakan Hutang Pada Perusahaan Manufaktur Yang Terdaftar Di Bursa Efek Indonesia Periode 2016 - 2018”. 


\section{LANDASAN TEORITIS DAN HIPOTESIS}

\subsection{Pengaruh kepemilikan institusional terhadap kebijakan hutang}

Kepemilikan institusional memiliki pengaruh tidak searah dengan prediksi kebijakan utang perusahaan. Semakin tinggi kepemilikan institusional, maka akan semakin rendah kebijakan utang perusahaan. Kepemilikan institusional yang lebih besar bila dibandingkan dengan pemegang saham kelompok lain dalam suatu perusahaan membuat kepemilikan intitusional memiliki wewenang yang besar. Kehadiran kepemilikan institusional mempunyai pengaruh yang signifikan terhadap kebijakan hutang, seperti yang dikatakan oleh Moh'd et al (1998 dalam (Fitriyah \& Hidayat, 2011)) menunjukkan bahwa institutional ownership pada industri manufaktur di BEI berperan sebagai pengawas atau monitoring dalam perilaku manajemen perusahaan dan juga dalam perilaku manajer pada pengambilan keputusan pendanaan dengan tujuan agar pihak manajemen bekerja lebih efisien untuk kepentingan para pemegang saham dimana hal ini dibuktikan berdasarkan hasil penelitian yang dilakukan oleh Nuraina (2012), Indahningrum \& Ratih (2009), Larasati (2011), Murtiningtyas (2012), menunjukkan bahwa kepemilikan Institusional berpengaruh positif terhadap kebijakan hutang.

\subsection{Pengaruh ukuran perusahaan terhadap kebijakan hutang}

Ukuran perusahaan merupakan gambaran dari besar kecilnya suatu perusahaan yang ditentukan berdasarkan sebuah ukuran yang dapat dinilai seperti total aktiva, total penjualan, dan kapitalisasi pasar. Besar kecilnya ukuran suatu perusahaan akan berpengaruh terhadap stuktur modalnya. Menurut Prasetyorini dalam Hery (2017:11), semakin besar ukuran atau skala perusahaan maka akan semakin mudah bagi perusahaan dalam memperoleh sumber pendanaan, baik bersifat internal maupun eksternal. Perusahaan yang besar dapat dengan mudah mengakses pasar modal. Karena kemudahan tersebut perusahan memiliki fleksibilitas dan kemampuan untuk mendapatkan dana baik melalui saham maupun utang. Perusahaan besar akan lebih mudah mendapatkan utang karena perusahaan besar biasanya mempunyai aset yang lebih banyak. Salah satu alasannya perusahaan lebih mudah menerima pinjaman adalah karena nilai aset yang dijadikan jaminan lebih besar dan tingkat kepercayaan bank juga lebih tinggi. Perusahaan besar memiliki keuntungan aktivitas serta lebih dikenal oleh publik dibandingkan dengan perusahaan kecil sehingga kebutuhan hutang perusahaan yang besar akan lebih tinggi dari perusahaan kecil (Smith, 1996 dalam Mulianti, 2009). Dimana hal ini dibuktikan oleh hasil penelitian oleh Dwi dkk (2012), Ifada \& Yunandriatna (2017), Yuana dkk (2018) mengenai ukuran perusahaan terhadap kebijakan hutang berpengaruh positif.

\subsection{Pengaruh profitabilitas terhadap kebijakan hutang}

Rasio profitabilitas (profitability ratio) menurut Fahmi (2017:135) adalah "rasio yang menghubungkan laba dari penjualan dan investasi". Rasio ini menilai kemampuan perusahaan dalam mencapai keuntungan . Untuk dapat melangsungkan hidupnya, perusahaan harus berada dalam keadaan yang menguntungkan (profitable). Apabila perusahaan berada dalam kondisi yang tidak menguntungkan, maka akan sulit bagi perusahaan untuk memperoleh pinjaman dari kreditor maupun investasi dari pihak luar. Dalam penelitian ini rasio profitabilitas menggunakan proksi Return On Assets (ROA). Return on assets (ROA) merupakan rasio yang digunakan untuk mengukur seberapa besar jumlah laba bersih yang akan dihasilkan dari setiap rupiah dana yang tertanam dalam total aset, yang diperoleh dengan membagi laba/rugi bersih dengan total aset. Penelitian yang dilakukan oleh Narita (2012), mengenai pengaruh profitabilitas terhadap kebijakan hutang menyatakan bahwa profitabilitas berpengaruh terhadap kebijakan hutang. 


\subsection{Pengaruh pertumbuhan penjualan terhadap kebijakan hutang}

Menurut Brigham dan Houston (2011:321), semakin tinggi tingkat pertumbuhan penjualan, suatu perusahaan akan lebih banyak mengandalkan modal eksternal. Perusahaan yang tingkat pertumbuhan penjualannya relatif tinggi dimungkinkan untuk dibelanjai dengan menggunakan utang lebih besar dibandingkan dengan perusahaan yang pertumbuhan penjualannya rendah, karena keuntungan yang diperoleh dari peningkatan penjualan tersebut diharapkan masih bisa menutup biaya bunga utang. Menurut Brigham dan Gapenski (1996), pertumbuhan perusahaan yang tinggi membutuhkan sumber dana yang tinggi pula untuk menjaga perusahaan akan tetap tumbuh, sehingga untuk memenuhi kebutuhan dananya, perusahaan menggunakan sumber dana eksternal yang lebih besar karena dana internal tidak mencukupi. Perusahaan yang penjualannya relatif stabil dari waktu ke waktu dimungkinkan untuk dibelanjai dengan utang yang lebih banyak dibandingkan dengan perusahaan yang penjualannya sangat berfluktuasi atau bersifat musiman, karena jika menggunakan utang dalam jumlah yang besar dengan beban bunga yang tetap, perusahaan yang penjualannya bersifat musiman dapat menghadapi kesulitan keuangan ketika sedang tidak musimnya atau saat penjualan mengalami penurunan (Sudana,2011:162). Hasil penelitian oleh Margaretha (2014), Susanti (2014), Yuana dkk (2018) mengenai pertumbuhan penjualan terhadap kebijakan hutang berpengaruh negative.

Berdasarkan uraian diatas, maka dapat digambarkan kerangka berpikir pada penelitian ini,yaitu:

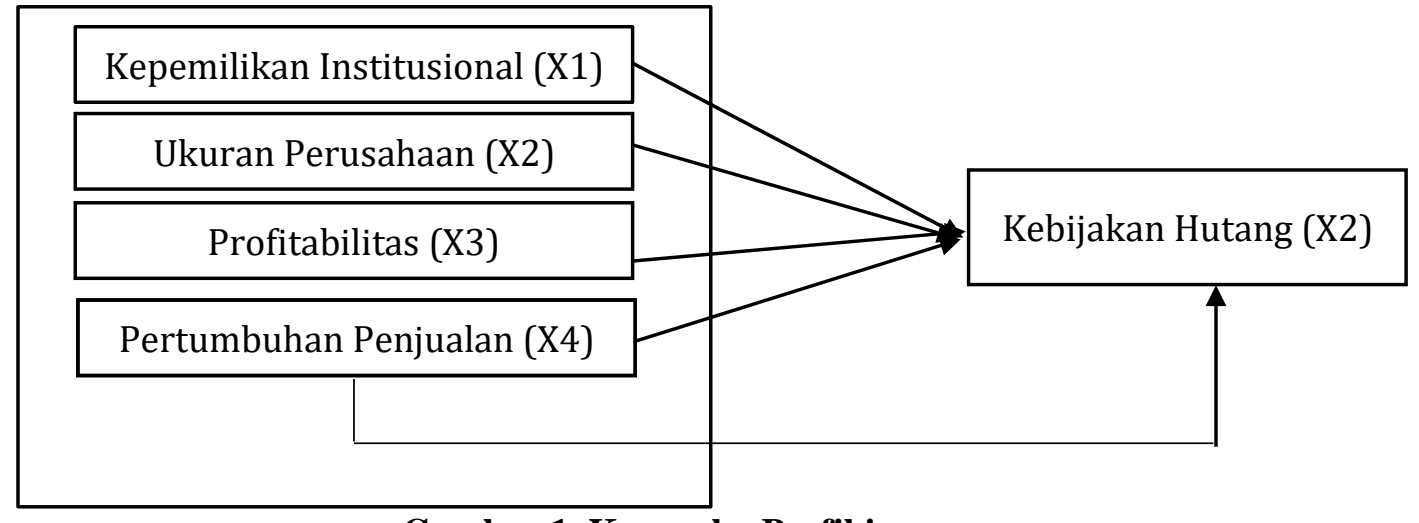

Gambar 1. Kerangka Berfikir

Berdasarkan uraian dari kerangka berpikir, maka hipotesis yang dirumuskan dalam penelitian ini, adalah:

H1: Kepemilikan Institusional secara signifikan berpengaruh terhadap Kebijakan Hutang. H2: Ukuran Perusahaan secara signifikan berpengaruh terhadap Kebijakan Hutang.

H3 : Profitabilitas secara signifikan berpengaruh terhadap Kebijakan Hutang.

H4: Pertumbuhan Penjualan secara signifikan berpengaruh terhadap Kebijakan Hutang.

H5 : Kepemilikan Institusional, Ukuran Perusahaan, Profitabilitas, dan Pertumbuhan

Penjualan secara simultan berpengaruh terhadap Kebijakan Hutang.

\section{METODE}

Penelitian ini dilakukan pada perusahaan-perusahaan manufaktur yang terdaftar di Bursa Efek Indonesia (BEI) periode 2016-2018. Penelitian ini dilakukan pada bulan Februari 2020 sampai dengan Maret 2020. Populasi dalam penelitian ini adalah seluruh perusahaan manufaktur yang terdaftar di Bursa Efek Indonesia (BEI) pada tahun 2016-2018. Pemilihan sampel penelitian dilakukan dengan cara pusposive sampling. Sampel yang digunakan adalah sampel yang memiliki kriteria sebagai berikut: 
1. Perusahaan yang terdaftar dan menerbitkan laporan keuangan tahunan (annual report) selama periode 2016 - 2018 yang telah diaudit oleh akuntan publik sehingga lebih lengkap dan terpercaya.

2. Perusahaan yang membuat laporan keuangan dengan satuan mata uang rupiah.

3. Perusahaan manufaktur yang memiliki nilai ekuitas dan laba positif dalam laporan keuangan periode $2016-2018$.

4. Perusahaan manufaktur yang memiliki informasi kepemilikan institusional dalam laporan keuangan periode 2016 - 2018.

5. Perusahaan manufaktur yang mengalami pertumbuhan penjualan selama periode penelitian.

Metode pengumpulan data yang digunakan dalam penelitian ini adalah observasi secara tidak langsung, di mana observasi dilakukan dengan mengunduh obyek material yang terkait dengan analisis yang dibutuhkan yaitu laporan keuangan perusahaan manufaktur yang terdaftar di Bursa Efek Indonesia (BEI) periode 2016-2018 yang bersumber dari website masing-masing perusahaan dan website www.idx.co.id. Teknik analisis yang digunakan dalam penelitian ini adalah metode analisis regresi berganda yaitu metode regresi yang memiliki lebih dari satu variabel independen, metode ini dipilih karena dapat menyimpulkan secara langsung mengenai masing - masing variabel bebas yang digunakan secara parsial maupun simultan. Pengelolaan metode ini menggunakan program Software Statistical Package Social Sciences (SPSS).

\subsection{Definisi Operasional}

\section{Kebijakan Hutang}

Kebijakan Hutang merupakan Kebijakan yang diambil dengan mempertimbangkan ekuitas yang ada didalam perusahaan, variabel dependen dalam penelitian ini diukur dengan DER (Debt to Equity Ratio (DER). DER adalah ukuran yang dipakai dalam menganalisis laporan keuangan untuk memperlihatkan besarnya jaminan yang tersedia untuk kreditor. Rasio ini dapat mengukur besarnya proporsi utang terhadap modal. Dimana rasio ini juga digunakan untuk memberi pengetahuan tentang besarnya perbandingan antara jumlah dana yang disediakan oleh kreditor dengan jumlah dana yang berasal dari pemilik perusahaan, dimana semakin tinggi rasio ini mengindikasikan bahwa semakin besar hutang yang diambil dalam membiayai kegiatan operasionalnya dibandingkan dengan menggunakan ekuitas. Berikut adalah rumus yang digunakan untuk menghitung rasio utang terhadap modal (Kasmir, 2018:158) adalah:

Der= Total Hutang (Debt) / Total Ekuitas ( Equity)

\section{Kepemilikan Institusional}

Komposisi pemegang saham dalam perusahaan yang berasal dari eksternal seperti perusahaan asuransi, bank, perusahaan investasi dan lembaga-lembaga institusi lainnya yang tersaji dalam laporan keuangan berupa persentase dari masing-masing kepemilikan saham. Keberadaan kepemilikan institusional di dalam perusahaan berperan sebagai monitoring pengawasan terhadap kinerja para manajer agar dapat berjalan dengan optimal. Dimana kepemilikan institusional ini juga memiliki peranan yang sangat penting dalam meminimalisir konflik keagenan yang terjadi antara manajer dan pemegang saham. Hal ini dikarenakan dengan adanya keterlibatan institusional dalam kepemilikan saham, manajemen perusahaan akan diawasi oleh investor - investor institusional sehingga kinerja manajemen juga akan meningkat.

Kepemilikan Institusional $=$ Jumlah saham yang dimiliki $/$ Jumlah saham yang beredar 


\section{Ukuran perusahaan}

Ukuran perusahaan merupakan gambaran dari besar kecilnya suatu perusahaan yang ditentukan berdasarkan ukuran yang dapat dinilai seperti total aktiva, total penjualan, dan kapitalisasi pasar. Ukuran perusahaan merupakan faktor yang perlu dipertimbangkan dalam menentukan struktur modal dan besar atau kecilnya sebuah perusahaan dapat menggambarkan seberapa besarnya perusahaan dalam membutuhkan dana untuk menunjang kegiatan operasionalnya. Ukuran perusahaan dalam penelitian ini diukur dengan menggunakan total aktiva yang dirumuskan sebagai berikut :

\section{Size $=$ Ln Total Aktiva}

\section{Profitabilitas}

Profitabilitas adalah kemampuan perusahaan dalam menghasilkan laba dalam hubungannya dengan penggunaan aset selama satu periode yang terdapat dalam laporan keuangan. Rasio profitabilitas diproksikan dengan rasio return on asset (ROA). Rasio ini menunjukkan kemampuan dari aset yang di investasikan dalam keseluruhan untuk menghasilkan laba. Dimana apabila rasio ini semakin tinggi maka menggambarkan semakin tinggi pula kemampuan perusahaan dalam memperoleh keuntungan. ROA mencerminkan tingkat keuntungan bersih setelah pajak yang juga berarti suatu ukuran untuk menilai seberapa besar tingkat pengembalian dari aset yang dimiliki perusahaan. Rasio ini dapat ukur menggunakan rumus (Situmeang 2014:67) :

Roa $=($ Laba bersih setelah pajak / Total Asset $) * 100 \%$

\section{Pertumbuhan Penjualan}

Pertumbuhan penjualan adalah kenaikan jumlah penjualan dari tahun ke tahun atau dari waktu ke waktu. Pertumbuhan penjualan merupakan volume penjualan pada tahun tahun mendatang berdasarkan data pertumbuhan volume penjualan historis. Tingkat pertumbuhan penjualan adalah hasil perbandingan antara selisi penjualan tahun berjalan dengan penjualan ditahun sebelumnya. Pertumbuhan penjualan dapat dihitung dengan rumus (Harahap 2016:309) sebagai berikut :

Pertumbuhan Penjualan $=($ Penjualan $(t)-$ Penjualan $(t-1)) /$ Penjualan $(t-1) * 100 \%$

Penjualan $(\mathrm{t})=$ penjualan tahun berjalan

Penjualan $(\mathrm{t}-1)=$ penjualan tahun sebelumnya

\section{HASIL DAN PEMBAHASAN}

\subsection{Uji Hipotesis}

\section{Uji Simultan (Uji F)}

Uji simultan (Uji statistik F) digunakan untuk menguji besarnya pengaruh dari seluruh variabel penelitian secara bersama-sama atau simultan terhadap variabel dependen (Ghozali, 2018). Hasil pengujian uji simultan (uji F) dalam penelitian ini ditunjukkan dalam tabel di bawah :

Tabel 1. Hasil Uji Simultan ( Uji F ) ANOVAa

\begin{tabular}{rrccccc}
\hline \multicolumn{1}{r}{ Model } & Sum of Square & Df & Mean Square & F & Sig \\
\hline \multirow{2}{*}{ Regression } & 10,911 & 4 & 2,728 & 14,241 & $000 \mathrm{~b}$ \\
& Residual & 18,579 & 97 &, 192 & & \\
& Total & 29,489 & 101 & & & \\
\hline
\end{tabular}

a. Dependent Variable : DER

b. Predictors : (Cosntant), PP, ROA, SIZE, KI

Berdasarkan hasil pengolahan SPSS pada tabel diatas, dapat dilihat bahwa F-hitung adalah sebesar 14,241 dengan nilai F-tabel adalah sebesar 2,47. Hal ini menunjukkan nilai F-hitung 14,241 > F-tabel 2,47 sedangkan tingkat signifikansi sebesar 0,000 < 0,05. Maka dapat disimpulkan bahwa kepemilikan institusional, ukuran perusahaan, profitabilitas, dan pertumbuhan penjualan berpengaruh secara simultan (bersama - sama) terhadap kebijakan hutang. Sehingga, dapat disimpulkan H5 diterima. 


\section{Uji Parsial (Uji T)}

Uji parsial digunakan untuk mengetahui pengaruh masing-masing variabel independen terhadap variabel dependen (Ghozali, 2018). Uji statistik t pada dasarnya menunjukan seberapa jauh pengaruh satu variabel penjelas/independen secara individual dalam menerangkan variasi variabel dependen. Kriteria yang digunakan dalam mengambil keputusan yaitu apabila T-hitung > T-tabel pada $\alpha=5 \%$ dan nilai probabilitas $<$ level of significant sebesar 0,05 , maka variabel independen berpengaruh terhadap variabel dependen. Namun, apabila T-hitung < T-tabel pada $\alpha=5 \%$ dan nilai probabilitas $>$ level of significant sebesar 0,05, maka variabel independen tidak berpengaruh terhadap variabel dependen. Berikut hasil pengujian untuk uji parsial (uji t):

Tabel 2. Hasil Uji Parsial (Uji T)

\begin{tabular}{|c|c|c|c|c|c|c|}
\hline \multicolumn{2}{|c|}{ Model } & \multicolumn{2}{|c|}{ Unstandardized Coefficients } & Standardized & $\mathbf{T}$ & Sig. \\
\hline & & B & Std. Error & Beta & & \\
\hline 1 & (Constant) & 2,383 & 1,045 & & 2,280 & ,025 \\
\hline & $\mathrm{KI}$ &,- 844 & ,301 &,- 241 & $-2,803$ & ,006 \\
\hline & SIZE &,- 021 & 034 &,- 053 &,- 621 & ,536 \\
\hline & $\mathrm{ROA}$ &,- 061 &, 009 &,- 579 & $-6,709$ & 000 \\
\hline & $\mathrm{PP}$ & ,015 &, 005 & ,236 & 2,922 & ,004 \\
\hline
\end{tabular}

a. Dependent Variable : DER

Nilai Ttabel pada $\alpha=0,05$; dengan df: $\mathrm{n}-(\mathrm{k}+1) ; 102-(4+1)=97$ uji dua arah adalah sebesar 1,98472, maka dapat dijelaskan sebagai berikut :

1. Hipotesis pertama (H1) dalam penelitian ini adalah kepemilikan institusional berpengaruh terhadap kebijakan hutang. Hasil uji t pada variabel kepemilikan institusional menghasilkan nilai T-hitung $-2.803>$ nilai T-tabel sebesar $-1,98472$ dengan tingkat signifikansi $0,006<0,05$, yang berarti kepemilikan institusional berpengaruh signifikan terhadap kebijakan hutang. Sehingga , dapat disimpulkan H1 diterima.

2. Hipotesis kedua (H2) dalam penelitian ini adalah ukuran perusahaan berpengaruh terhadap kebijakan hutang. Hasil uji t pada variabel ukuran perusahaan menghasilkan nilai T-hitung sebesar $-0,621<$ nilai T-tabel sebesar -1,98742 dengan tingkat signifikansi 0,536 > 0,05 yang berarti ukuran tidak berpengaruh signifikan terhadap kebijakan hutang. Sehingga, dapat disimpulkan $\mathrm{H} 2$ ditolak.

3. Hipotesi ketiga (H3) dalam penelitian ini adalah profitabilitas berpengaruh terhadap kebijakan hutang. Hasil uji t pada variabel profitabilitas menghasilkan nilai T-hitung sebesar $-6,709>$ nilai T-tabel sebesar -1,98742 dengan tingkat signifikansi $0,000<$ 0,05 yang berarti profitabilitas berpengaruh signifikan terhadap kebijakan hutang. Sehingga, dapat disimpulkan $\mathrm{H} 3$ diterima.

4. Hipotesis keempat $(\mathrm{H} 4)$ dalam penelitian ini adalah pertumbuhan penjualaan. Hasil uji t pada variabel pertumbuhan penjualan menghasilkan nilai T-hitung sebesar 2,922 > nilai T-tabel sebesar 1,98742 dengan tingkat signifikansi $0,004<0,05$ yang berarti pertumbuhan penjualan berpengaruh signifikan terhadap kebijakan hutang. Sehingga, dapat disimpulakan $\mathrm{H} 4$ diterima.

\section{Koefisien Determinasi (R2)}

Koefisien determinasi (R2) pada intinya mengukur seberapa jauh kemampuan model dalam menerangkan variabel dependen. Nilai R2 yang kecil berarti kemampuan variabel independen dalam menjelaskan variabel dependen amat terbatas. Nilai yang mendekati satu berarti variabel-variabel independen memberikan hampir semua informasi yang dibutuhkan 
untuk memprediksi variasi variabel dependen (Ghozali, 2018). Hasil yang diperoleh dari uji koefisien determinasi (R2) dapat dilihat pada tabel berikut ini:

Tabel 3. Hasil Uji Koefisien Determinasi (R2)

$\begin{array}{lllll}\text { Model } & \mathrm{R} & \mathrm{R} \text { Square } & \text { Adjusted R Square } & \text { Std. Error of the Estimate } \\ 1 & , 608 \mathrm{a} & , 370 & , 344 & , 43764\end{array}$

a. Predictors : Constant, PP, ROA, SIZE, KI

b. Dependent Variabel DER

Berdasarkan tabel diatas diketahui bahwa Nilai Adjusted $R$ Square sebesar 0,344 atau 34,4\%. Hal ini menunjukkan bahwa variabel kepemilikan institusional, ukuran perusahaan, profitabilitas, dan pertumbuhan penjualan dapat menjelaskan variabel kebijakan hutang sebesar $34,4 \%$, sedangkan sisanya sebesar $65,6 \%$ dijelaskan oleh variabel lain diluar model penelitian ini.

\section{PEMBAHASAN HASIL PENELITIAN}

\section{Pengaruh kepemilikan institusional terhadap kebijakan hutang}

Hasil uji t pada variabel kepemilikan institusional menghasilkan nilai T-hitung -2.803>nilai T-tabel sebesar $-1,98472$ dengan tingkat signifikansi $0,006<0,05$, yang berarti kepemilikan institusional berpengaruh signifikan terhadap kebijakan hutang. Sehingga, dapat disimpulkan H1 diterima. Tanda negatif pada koefisien T-hitung yakni -2,803 menunjukkan bahwa prediksi dari adanya kepemilikan institusional atau kepemilikan dari pihak luar seperti, asuransi, koperasi, pemerintah ataupun lembaga lain dengan keputusan pendanaan hutang perusahaan bersifat tidak searah, Arah negatif dari penelitian ini menunjukkan bahwa semakin tinggi kepemilikan institusional maka akan semakin rendah kebijakan hutang perusahaan. Hal ini dikarenakan tingginya persentase kepemilikan institusional yang dimiliki pihak pemegang saham dapat mengawasi manajemen perusahaan dengan optimal, sehingga manajemen perusahaan akan menurunkan penggunaan hutang karena hutang memiliki resiko kebangkrutan yang akan berdampak pada kesejahteraan pemegang saham. Berdasarkan hasil penelitian ini dapat disimpulkan bahwa kepemilikan institusional yang tinggi dapat mengawasi manajemen secara optimal, tindakan monitoring tersebut akan mengurangi biaya keagenan karena memungkinkan perusahaan menggunakan tingkat hutang yang lebih rendah untuk mengantisipasi kemungkinan terjadinya financial distress dan kebangkrutan perusahaan.

\subsubsection{Pengaruh ukuran perusahaan terhadap kebijakan hutang}

Hasil uji t pada variabel ukuran perusahaan menghasilkan nilai T-hitung sebesar $-0,621<$ nilai T-tabel sebesar -1,98742 dengan tingkat signifikansi 0,536>0,05 yang berarti ukuran perusahaan tidak berpengaruh signifikan terhadap kebijakan hutang. Sehingga, dapat disimpulkan $\mathrm{H} 2$ ditolak. Berdasarkan hasil penelitian ini dijelaskan bahwa ukuran perusahaan (total asset) yang bernilai besar tidak menjamin perusahaan memiliki nilai yang konsisten dimasa mendatang sehingga pihak manajemen perusahaan manufaktur tidak ingin menanggung risiko dengan mengambil keputusan untuk menggunakan hutang sebagai sumber pendanaannya. Berdasarkan hasil penelitian ini bahwa aset yang besar bukan merupakan faktor utama yang dijadikan pertimbangan oleh kreditur dalam memberikan pinjaman, kreditur mungkin akan mengacu kepada faktor lain seperti tingkat suku bunga yang diperoleh atau kredibilitas manajer perusahaan. Berdasarkan hasil penelitian ini juga menunjukkan bahwa perusahaan juga tidak hanya menggunakan hutang dalam mendanai kegiatan operasional perusahaan.

\subsubsection{Pengaruh Profitabilitas terhadap kebijakan hutang}

Hasil uji t pada variabel profitabilitas menghasilkan nilai T-hitung sebesar -6,709>nilai Ttabel sebesar $-1,98742$ dengan tingkat signifikansi $0,000<0,05$ yang berarti profitabilitas berpengaruh negatif signifikan terhadap kebijakan hutang. Sehingga, dapat disimpulkan H3 diterima. Tanda negatif pada koefisien T-hitung yakni $-6,709$ menunjukkan bahwa prediksi dari adanya laba atas pengembalian aset atau dikenal dengan return on asset dengan keputusan pendanaan hutang perusahaan bersifat tidak searah, hal ini berarti apabila 
perusahaan tersebut memiliki laba yang didapatkan oleh hasil pengembalian aset tinggi atau besar maka pengambilan dana dari hutang menjadi turun atau rendah, hal ini mendukung teori yang mengatakan bahwa semakin tinggi tingkat profitabilitas perusahaan khususnya pada laba atas hasil pengembalian aset perusahaan maka perusahaan tidak perlu menggunakan dana dari luar atau eksternal berupa hutang karena sisa laba ditahan dari hasil return on asset masih memadai untuk memenuhi kegiatan operasional perusahaan tersebut. Hal ini menyatakan bahwa perusahaan yang memiliki profitabilitas yang relatif tinggi akan cenderung menggunakan utang yang lebih kecil, karena perusahaan akan mampu menyediakan banyak dana untuk kegiatan operasionalnya dengan menggunakan sumber dana internalnya yaitu laba ditahan terlebih dahulu daripada harus menggunakan sumber dana eksternal yaitu utang yang akan menimbulkan risiko cukup besar bagi perusahaan.

\subsubsection{Pengaruh Pertumbuhan penjualan terhadap kebijakan hutang}

Hasil uji t pada variabel pertumbuhan penjualan menghasilkan nilai T-hitung sebesar 2,922>nilai T-tabel sebesar 1,98742 dengan tingkat signifikansi $0,004<0,05$ yang berarti pertumbuhan penjualan berpengaruh positif signifikan terhadap kebijakan hutang. Sehingga, dapat disimpulakan $\mathrm{H} 4$ diterima. Hal ini mengindikasikan bahwa perusahaan yang memiliki tingkat pertumbuhan penjualan yang tinggi cenderung membutuhkan dana ekternal yang lebih besar untuk mengembangkan usahanya seperti diversifikasi produk, promosi, distribusi dan sebagainya. Berdasarkan hasil penelitian ini dapat disimpulkan bahwa semakin tinggi tingkat pertumbuhan penjualan, suatu perusahaan akan lebih banyak mengandalkan modal eksternal.

\subsubsection{Pengaruh kepemilikan institusional, ukuran perusahaan, profitabilitas, dan pertumbuhan penjualan terhadap kebijakan hutang}

Hal ini menunjukkan nilai F-hitung 14,241 > F-tabel 2,47 dengan tingkat signifikansi sebesar $0,000<0,05$. Maka dapat disimpulkan bahwa kepemilikan institusional, ukuran perusahaan, profitabilitas, dan pertumbuhan penjualan berpengaruh secara simultan (bersama - sama) terhadap kebijakan hutang. Sehingga, dapat disimpulkan H5 diterima. Hasil ini menunjukkan bahwa kepemilikan institusional, ukuran perusahaan, profitabilitas dan pertumbuhan penjualan merupakan faktor-faktor yang harus diperhatikan perusahaan dalam melakukan kebijakan hutang. Semakin tinggi kepemilikan institusional maka semakin rendah kebijakan hutang, hal ini disebabkan karena semakin tingginya persentase kepemilikan institusional yang dimiliki pihak pemegang saham dapat mengawasi manajemen perusahaan dengan optimal, sehingga manajemen perusahaan akan menurunkan penggunaan hutang karena hutang memiliki resiko kebangkrutan yang akan berdampak pada kesejahteraan pemegang saham. ukuran perusahaan (total asset) yang bernilai besar tidak menjamin perusahaan memiliki nilai yang konsisten dimasa mendatang sehingga pihak manajemen perusahaan manufaktur tidak ingin menanggung risiko dengan mengambil keputusan untuk menggunakan hutang sebagai sumber pendanaannya. Semakin tinggi profitabilitas yang dihasilkan oleh perusahaan maka akan semakin rendah kebijakan hutang, hal ini dikarenakan perusahaan yang memiliki profitabilitas yang relatif tinggi akan cenderung menggunakan utang yang lebih kecil, karena perusahaan akan mampu menyediakan banyak dana untuk kegiatan operasionalnya dengan menggunakan sumber dana internalnya yaitu laba ditahan terlebih dahulu daripada harus menggunakan sumber dana eksternal yaitu utang yang akan menimbulkan risiko cukup besar bagi perusahaan.

Semakin tinggi pertumbuhan penjualan suatu perusahaan maka akan semakin tinggi pula perusahaan melakukan kebijakan hutang, hal ini dikarenakan perusahaan yang memiliki tingkat pertumbuhan penjualan yang tinggi cenderung membutuhkan dana ekternal yang lebih besar. Selain itu para investor juga akan menilai dan yakin kepada perusahaan jika perusahaan tersebut dapat mengelola utangnya dengan baik dan mampu menangani risiko atas utang tersebut, sehingga perusahaan akan menambah tingkat hutangnya. 


\section{KESIMPULAN DAN SARAN}

\subsection{Kesimpulan}

Berdasarkan permasalahan penelitian, kajian teori, hasil penelitian, dan pembahasan, maka dapat disimpulkan sebagai berikut:

1. Kepemilikan institusional berpengaruh negatif signifikan terhadap kebijakan hutang.

2. Ukuran perusahaan tidak berpengaruh terhadap kebijakan hutang.

3. Profitabilitas berpengaruh negatif signifikan terhadap kebijakan hutang.

4. Pertumbuhan penjualan berpengaruh positif signifikan terhadap kebijakan hutang.

5. Hasil penelitian uji secara simultan menyatakan bahwa kepemilikan institusional, ukuran perusahaan, profitabilitas, dan pertumbuhan penjualan berpengaruh secara bersama-sama dan signifikan terhadap kebijakan hutang.

\subsection{Saran}

Berdasarkan analisis yang telah dilakukan, maka peneliti memberikan saran sebagai berikut:

6. Penelitian ini hanya membahas terkait pengaruh kepemilikan institusional, ukuran perusahaan, profitabilitas dan pertumbuhan penjualan terhadap kebijakan hutang dengan hasil koefisien determinasi (R2) sebesar 34,4\% sedangkan sisanya sebesar $65,6 \%$ dijelaskan oleh variabel lain diluar variabel - variabel tersebut. Oleh karena itu, bagi peneliti selanjutnya agar menambahkan variabel - variabel lain yang diprediksi dapat mempengaruhi kebijakan hutang seperti arus kas bebas, struktur aset, resiko bisnis, tarif pajak, kepemilikan asing, kebijakan deviden, dan lain sebagainya.

7. Penelitian ini hanya melakukan penelitian pada objek perusahaan manufaktur yang terdaftar di BEI. Oleh karena itu, peneliti menyarankan agar peneliti selanjutnya dapat meneliti dengan objek yang berbeda seperti perusahaan dagang atau jasa, sehingga dapat memperluas ruang lingkup penelitian agar tidak pada perusahaan manufaktur saja.

8. Penelitian ini hanya dilakukan pada periode 2016 - 2018, sehingga peneliti selanjutnya sebaiknya dapat menambah rentang waktu periode penelitian, agar hasil penelitian lebih konsisten 


\section{DAFTAR PUSTAKA}

Amirya, Mirna and Sari Atmini. 2008. "Determinan Tingkat Hutang Serta Hubungan Tingkat Hutang Terhadap Nilai Perusahaan: Perspektif Pecking Order Theory." Jurnal Akuntansi Dan Keuangan Indonesia 5(2):227-44.

Astuti, Elly. 2012. "Jurnal Akuntansi Dan Pajak Vol. 15 No. 02, Januari 2014.” 14(02):14958.

Badan pengawas pasar, Modal. 1997. "Keputusan Ketua Badan Pengawas Pasar Modal Nomor KEP- $\quad$ 11/PM/1997." Departemen Keuangan Republik Indonesia.

Brigham, Eugene F. and Joel F. Houston. 2006. Dasar - Dasar Manajemen Keuangan. 10th ed. edited by S. Empat. Jakarta.

Brigham, Eugene F. and Joel F. Houston. 2011. Dasar - Dasar Manajemen Keuangan. buku 1, ed. Jakarta: Salemba Empat.

Fahmi, Irham. 2014. Analisis Kinerja Keuangan. Bandung: Alfabeta. 2017. Analisis Laporan Keuangan. edisi enam. Bandung: Alfabeta.

Firnanti, Friska. 2011. "Faktor-Faktor Yang Mempengaruhi Struktur Modal PadaPerusahaan Manufaktur Y Yang Go Public.” Jurnal Bisnis Dan Akuntansi 13(2):119-28.

Fitriyah, Fury K. 2011. "Pengaruh Kepemilikan Institusional, Set Kesempatan Investasi Dan Arus Kas Bebas." Media Riset Akuntansi 1(1):31-76.

Ghozali, Imam. 2018. Aplikasi Analisis Multivariate Dengan Program IBM SPSS 25. Semarang: Badan Penerbit Universitas Diponegoro.

Harahap, Sofyan Syafri. 2016. Analisis Kritis Atas Laporan Keuangan. Jakarta: Rajawali Pers.

Hery. 2017. Analisis Laporan Keuangan : Integrated and Comprehensive. 2nd ed. edited by P. Grasindo. Jakarta.

Indahningrum, Rizka Putri and Ratih Handayani. 2009. "Pengaruh Kepemilikan Manajerial, Kepemilikan Institusional, Dividen, Perumbuhan Perusahaan, Free Cash Flow Dan Profitabilitas Terhadap Kebijakan Hutang Perusahaan.” Jurnal Bisnis Dan Akuntansi 11(3):189-207.

Irawan, arif; Rina arifati; Abrar Oemar. 2016. "Pengaruh Aset Berwujud, Ukuran Perusahaan, Pertumbuhan Perusahaan, Lama Perusahaan Dan Profitabilitas Terhadap Kebijakan Hutang Pada Perusahaan Manufaktur Yang Terdaftar Di Bursa Efek Indonesia Periode Tahun 2010-2014.” Journal Of Accounting 2.

Kasmir. 2018. Analisis Laporan Keuangan. edisi 1, c. Jakarta: Rajawali Pers.

Larasati, eva. 2011. "Pengaruh Kepemilikan Manajerial, Kepemilikan Institusional, Dan Kebijakan Hutang Terhadap Tax Aggressive." JOM Fekon 3(1):1137-49.

Mardiyati, Umi, Qothrunnada Qothrunnada, and Destria Kurnianti. 2018. "Pengaruh Kepemilikan Manajerial, Struktur Aktiva, Ukuran Perusahaan, Pertumbuhan Penjualan Dan Profitabilitas Terhadap Kebijakan Utang Pada Perusahaan Sektor Aneka Industri Yang Terdaftar Di Bursa Efek Indonesia (Bei) Periode 2012 2016.” JRMSI - Jurnal Riset Manajemen Sains Indonesia 9(1):105-

Moh'd et, Al. 1998. "The Impact of Ownership Structure on Corporate Debt Policy : A TimeSeries Cross-

Sectional Analysis." Financial Review 85-89.

Nafisa Adita, Atim Dzajuli, and Djumahir -. 2016. "Pengaruh Kepemilikan Manajerial, Kepemilikan Institusional, Ukuran Perusahaan, Pertumbuhan Perusahaan, Free Cash Flow Dan Profitabilitas Terhadap Kebijakan Hutang Perusahaan Manufaktur Di Bursa Efek Indonesia.” Ekonomi Bisnis 21(2):122-35.

Pradhana, Afi, Taufeni Taufik, and Lila Anggraini. 2014. "Pengaruh Ukuran Perusahaan, Profitabilitas, Dan Pertumbuhan Penjualan Terhadap Kebijakan Hutang Pada Perusahaan Food and Beverages Yang Terdaftar Di Bursa Efek Indonesia.” Jurnal Online Mahasiswa Fakultas Ekonomi Universitas Riau 1(2). 
Ramadhani, Suci and Dkk. 2018. "Kebijakan Hutang Pada Perusahaan Sektor Utama Yang Terdaftar Di Bursa Efek Indonesia Periode 2013-2016.” Jurnal Akuntansi 8(2):12738.

Saputra, M. angga; fatahurrazak; sri ruwanti. 2018. "Pengaruh Free Cash Flow, Pertumbuhan Perusahaan," 74(4):55-61.

Sawir, Agnes. 2004. Analisis Kinerja Keuangan Dan Perencanaan Keuangan Perusahaan. edited by P. G. P. Utama. Jakarta.

Situmeang, Chandra. 2014. Manajemen Keuangan. edisi pert. Medan: Unimed Press.

Sudana, I. made. 2011. Manajemen Keuangan Perusahaan Teori Dan Praktik. edited by Erlangga. Jakarta.

Sudiyatno, Bambang and Septavia Mustika Sari. 2013. "Determinants of Debt Policy: An Empirical Studying Indonesia Stock Exchange.” Educational Research 4(2):98108.

Susanti, Faria. 2013. "Pengaruh Likuiditas, Kebijakan Deviden, Struktur Aset, Ukuran Perusahaan Dan Pertumbuhan Penjualan Terhadap Kebijakan Hutang Pada Perusahaan Manufaktur Yang Terdaftar Di Bursa Efek Indonesia Tahun 2010 2013."

Syadeli, Moh. 2013. "Struktur Kepemilikan, Profitabilitas Dan Ukuran Perusahaan Terhadap Kebijakan Hutang Perusahaan Pemanufakturan Di Bursa Efek Indonesia." Jurnal Manajemen Dan Akuntansi 2:79-94.

Tjeleni, Indra. 2013. "Kepemilikan Manajerial Dan Institusional Pengaruhnya Terhadap Kebijakan Hutang Pada Perusahaan Manufaktur Di Bursa Efek Indonesia." Jurnal Riset Ekonomi, Manajemen, Bisnis $\quad$ Dan Akuntansi 1(3):129-39.

Wahyudin, Agus and Khansa' Salsabila. 2019. "Firm Size Moderates the Effect of Free Cash Flow, Firm Growth, and Profitability On Debt Policy." Jurnal Dinamika Akuntansi 11(1):89-97. 